\title{
New Approach to Control Sclerotium rolfsii Induced Sugar Beet Root Rots Disease by Trichoderma with Improved Sucrose Contents
}

\author{
Sawsan Abd Ellatif ${ }^{1 *}(\mathbb{D})$, Mohamed Medhat Gharieb², Soliman M. El-Moghazy ${ }^{3}$, \\ Mai N. Abo El-Yazied ${ }^{3}$ and Amal M. Bakry ${ }^{4}$
}

${ }^{1}$ Bioprocess development Department, Genetic Engineering and Biotechnology Research Institute, City for Scientific Research and Technology Application, New Borg El-Arab, 21934, Alexandria, Egypt. ${ }^{2}$ Faculty of Science, Menoufia University, Egypt. ${ }^{3}$ Plant Pathology Research Institute, Agriculture Research Center, Giza, Egypt. ${ }^{4}$ Maize and Sugar crop Disease Research Department, Plant Pathology Research Institute, ARC., Giza (Egypt).

\begin{abstract}
In Egypt, sugar beet (Beta vulgaris L.) has become a major sugar manufacturing plant in latest years. It is recognized that sugar beet damaged by different pathogens, including root rot disease caused by Sclerotium rollsii, in terms of quantity and quality. The aim of the current study was to control the disease of the root rot sugar beet and determine the sucrose content during two successive cropping seasons. Trichoderma harzianum kj831197 produced $\beta$ - glucanase enzymes that play a key role in fungal disease biocontrol. Twenty two bioactive isolates were tested for the activity of $\beta$-glucanases, ten of which are Trichoderma spp strains. Sclerotium rolfsii radial growth has been suppressed with efficiency ranging from $\mathbf{7 7 . 7 7}$ to $91.11 \%$ in dual culture technique. The Vitavax 200 fungicide increased control of the disease under greenhouse conditions followed by a combination of $\beta$-glucanase enzyme with Trichoderma harzianum kj831197 spore suspension. The use of $\beta$-glucanase enzyme mixed with Trichoderma harizianum kj831197 cells leads to an increase above other treatments in the total soluble solid and sucrose content of the sugar beet. Despite the fungicide Vitavax200, the overall soluble solid and sucrose content were significantly affected by disease control but the sugar beets yield was lowered.
\end{abstract}

Keywords: Sugar beet, Sclerotium rolfsii, Glucanase, Trichoderma, Biological control.

*Correspondence: sghany2000@yahoo.com

(Received: 05 June 2019; accepted: 09 July 2019)

Citation: Sawsan Abd Ellatif, Mohamed Medhat Gharieb, Soliman M. El-Moghazy, Mai N. Abo El-Yazied and Amal M. Bakry, New Approach to Control Sclerotium rolfsii Induced Sugar Beet Root Rots Disease by Trichoderma with Improved Sucrose Contents, J Pure Appl Microbiol., 2019; 13(3): 1595-1604. https://doi.org/10.22207/JPAM.13.3.32

(c) The Author(s) 2019. Open Access. This article is distributed under the terms of the Creative Commons Attribution 4.0 International License which permits unrestricted use, sharing, distribution, and reproduction in any medium, provided you give appropriate credit to the original author(s) and the source, provide a link to the Creative Commons license, and indicate if changes were made. 


\section{INTRODUCTION}

Egyptians already maintain the largest sugar consumption rates in the globe; reach at $34 \mathrm{~kg}$ per individual per year. The UN Food and Agriculture Organization say that the world's average percent sugar consumption is $23 \mathrm{~kg}$ per year. The Egyptian sugar industry is based on two primary cultivations, i.e. sugarcane and beet sugar. The former is in Upper Egypt Governorates and the latter in Lower Egypt Governorates. In the late last century, Egypt became known as sugar beet (Beta vulgaris $\mathrm{L}$.) Since then, it has especially in recent years become an economic crop. Furthermore, sugar beet saves much irrigated water as 2.5-3.0 thousand $\mathrm{m}^{3}$ of water are required per feddan during the whole season while sugarcane crop uses up 10-12 thousand $\mathrm{m}^{3}$ of water ${ }^{1}$ The sugar beet plant, inherited by the Amaranthaceae family, is mainly established in temperate climates suitable for sucrose manufacturing. It approximately constitutes one-third of sugar manufacturing worldwide. Sugar beet is reported to be damaged by numerous infections that influence its yield. Several findings stated that many harmful fungal diseases such as Alternaria spp. and Fusarium oxysporum, Rhizoctonia solani, Sclerotium rolfsii, Mucar spp., Phoma betae and Pythium aphanideramatum are correlated with sugar beetroot rots ${ }^{2-4}$. Sclerotium rolfsii Sacc, one of the most dangerous infectious organisms causing the damping-off of plant and root rot symptoms ${ }^{5}$. The principal reason for damping seedlings and root rot illnesses of sugar beet has been the plant pathogen basidiomycete Sclerotium rolfsii, which has to be controlled essentially by fungicides.

Excessive use of chemical fungicide has led in adding of dangerous to individuals and the ecosystem owing to toxic compounds ${ }^{6}$. Effective strategies to chemical regulation were studied to address these national and international challenges and one successful approach appears to be the use of antagonistic microorganisms ${ }^{7}$. Thus, there is an immediate need to find ecofriendly solutions such as the wider application of biocontrol agents.

Competition, parasitism, antibiotics, or by a conjunction of such methods of behavior can lead to antagonism ${ }^{8}$. The formation of numerous hydrolytic enzymes that deteriorate pathogenic fungal cell walls comprises parasitism ${ }^{9}$. Fungal genus Trichoderma produces different kinds of enzymes which play a major role in biocontrol activity like degradation of the cell wall, tolerance to biotic or a biotic stresses, hyphal growth etc.

Our previous data (under publication) in medium optimization giving rise of maximal glucanase enzyme production of 10 folds higher than the initial medium owing to the optimization of growth parameters. The optimal condition for enzyme production was highly increased by xylose as C- source $0.5 \%, 0.1 \mathrm{mM}$ tween- 80 and $2 \mathrm{mM}$ galactose added as an inducer, $\mathrm{pH} 5.5$, temp. $37{ }^{\circ} \mathrm{C}$, agitation $200 \mathrm{rpm}$, nitrogen source was malt extract at a conc. of $1 \%$. Through large scale production of $\beta$ - glucanase enzyme of the optimized medium in bench-scale bioreactor will be conducted. This work conducted for using the results to complete the picture by making a practical application in greenhouse experiment. The other main objective is the application of highly active $\beta$-glucanase enzyme and Trichoderma harizianum kj831197 as an eco-friendly biopesticide alternative to chemical pesticides.

\section{MATERIALS AND METHODS Chemicals}

Lichenan as glucanase substrate (purchased from Sigma-Aldrich), Dinitrosalicylic Acid (DNSA), other chemicals were of analytical grade.

\section{Bioreactor}

For large scale production of $\beta$-glucanase batch cultivation was achieved in a $3 \mathrm{~L}$ bench-top bioreactor (Bioflow III, New Brunswick, NJ, USA) supplied with two 6-bladed disc-turbine impeller and four baffles, and joined to a digital managing system. The process was computerized through the AFS BioCommand multi-process management system, computer-assisted data processing system and the limits set by mechanical filling of weak acid or base for the physical properties at a temperature of $30^{\circ} \mathrm{C}$ and $\mathrm{pH} 6$ were established. Originally compressed air was supplied by a sterile filter to $1.0 \mathrm{VVM}$. The dispersed oxygen level remained above $20 \%$ and can then be manually adjusted in addition to the agitation speed (200rpm). The dissolved oxygen level was above $20 \%$. The dissolved oxygen level ad $\mathrm{pH}$ values were determined online with Mettler Toledo electrodes and antifoams A (Sigma), 
for the elimination of foaming. Inoculums of Trichoderma harizianum kj831197 injected as spore suspension of $10 \%$ in the optimized medium used in fermentor which was xylose (C-source) $0.5 \%, 0.1 \mathrm{mM}$ tween- 80 and $2 \mathrm{mM}$ galactose added as an inducer, $\mathrm{pH} 5.5$, temp. $37^{\circ} \mathrm{C}$, agitation 200 rpm, nitrogen source was malt extract at a conc. of $1 \%$.

\section{Experimental design}

The present study was performed in two positions under laboratory and greenhouse circumstances. Sclerotium rolfsii the causal agent of sugar beet root rots disease was isolated from infected beet plants samples and bioagents isolates were detached from rhizosphere soil specimens. The bioagent showing the highest glucanase activity production was chosen for identification and further analyses. Identification has been made morphologically by the aid of a microscope and later by molecular means.

Estimation of the bioagents organisms for glucanase production

Glucanase enzyme was quantitative estimated using the method of Miller ${ }^{10}$, in which $1 \mathrm{~g}$ of DNSA dissolved in $50 \mathrm{ml}$ distilled water, $30 \mathrm{~g}$ of sodium-potassium tartrate slowly add. Stirring the mixture till complete dissociation, $20 \mathrm{ml}$ of $2 \mathrm{~N}$ $\mathrm{NaOH}$ added. All the above steps must be carried out in the dark bottle enclosed in aluminum foil as DNSA is light-sensitive solution, Store the bottle at room temperature and it must freshly prepare.

\section{Glucanase enzyme activity assay}

From Trichoderma harizianum kj831197 broth culture, $1 \mathrm{ml}$ culture centrifuged at 10,000 rpm for $10 \mathrm{~min}$, the supernatant constitute the extracellular enzyme production. For enzyme assay, prepare $0.5 \%$ lichenan as the substrate of glucanase enzyme in $0.1 \mathrm{M}$ phosphate buffer $\mathrm{pH}$ (4.5-5), enzyme assay mixture consisted of $0.5 \mathrm{ml}$ of the prepared substrate mixed with $0.5 \mathrm{ml}$ of the supernatant containing the enzyme in test tubes, incubate the tubes at $34^{\circ} \mathrm{C}$ in water bath for $20 \mathrm{~min}$, mix gently from time to time, stop the reaction by adding $1 \mathrm{ml}$ of DNSA, boil the tubes for $10 \mathrm{~min}$ at $100^{\circ} \mathrm{C}$, for blank tubes all previous contents added replacing the enzyme by $0.5 \mathrm{ml}$ of distilled water or the buffer, measure the absorbance at $540 \mathrm{~nm}$ against the blank. Glucanase activity was defined as 1 micromole of glucose released per minute under assay condition and this can be calculated according to Kumala et al. ${ }^{11}$.

Efficacy of the tested bio-control agent against sclerotium rolfsii under green-house conditions

Greenhouse study has been planned to estimate several treatments for Sclerotium rolfsii; i.e. culture of the bio-control agent, fungicide (Vetavax200) and clove (Syzygium aromaticum) in controlling sugar beet root-rotting. During the 2015/2016 and 2016/2017, the test was conducted.

Two techniques of implementation have been used, i.e. bio-control agents and seed treatment:

\section{Bio-formulation of bio-control agents}

In this experiment, Talc powder was used as a carrier substance for bio-formulation of Trichoderma biomass. Talc powder (300 meshes, white color) $2 \mathrm{Kg}$, carboxy methylcellulose/Gum Arabic powder $10 \mathrm{~g}$ and Gypsum powder $2 \mathrm{Kg}$ prepared. Construction of powder formulation was brought by running stationary culture approach. The biomass from the 15 day culture of Trichoderma prepared in flasks was utilized for the establishment of the formulation. The biomass along with the medium in conical flasks was mixed with a carrier in the rate of 1:2. The mixture was air-dried in shade for 3 to 4 day and blended to have an owing powder to which $0.5 \%$ sucker (CMC) Gum Arabic) was added. The formulation therefore developed was packed in white polythene bags at room condition and in the refrigerator $\left(4^{\circ} \mathrm{C}\right)$. The population evaluation was made at periodic intervals.

\section{Seed treatment}

Sugar beet seed (C.V. Kwamera) the extremely sensitive variety to root-rots was applied in the performing study. Seeds were carefully cleaned by tap water and dried in the dark previous to usage. According to Abd-El-Moity and Shatla ${ }^{12}$, Trichoderma harzianum kj831197 was cultivated in conical flasks $(250 \mathrm{ml})$ containing autoclaved $100 \mathrm{ml}$ molasses yeast extract broth (10g molasses, $1.6 \mathrm{~g}$ yeast extract and $990 \mathrm{ml}$ distilled water) at laboratory condition $\left(18-20^{\circ} \mathrm{C}\right)$ in the dark for 14 days. After the pass-by of the study time, the mature fungal growth was blended and refined applying filter sheet and the filtrate was gathered to apply in treating seeds. Dressed seeds with Vitavax 200 (Vitavaxtriram WP) at the approved dose $(30 \mathrm{~g} / \mathrm{Kg})$ were accepted as a 
control in the greenhouse study also seed dressed with glucanase enzyme of Trichoderma and treated seeds with clove oil at a dose $(25,000 \mathrm{ppm})$ were tested.

\section{Inoculums of sclerotium rolfsii}

The pathogen was developed on the sand and wheat $(2: 3 \mathrm{w} / \mathrm{w})$ into glass bottles for two weeks at $27^{\circ} \mathrm{C}$. After the establishment time, the cultivated fungus was adopted in invading clay soil at the rate of $2 \%$ of soil weight. The soil was, dispersed into clay pots, rinsed with tap water and allowed for one week to enable the infection to settle itself before sowing. Pots were, implanted with seeds (10 seeds/ pot), moistened and enriched as frequent. Four replicates/ treatment were valued and pots buried with untreated seeds served as control.

\section{Disease assessments}

Pre- and post-emergence damping off was scored after 15 and 45 days of planting, respectively, according to El-Shafey et al. ${ }^{13}$ as follows:

Pre-emergence damping-off $(\%)=($ No. of non-emerged seed/Total No. of seeds sown) $x$ 100. Post-emergence damping-off $(\%)=($ No. of wilted plant /Total No. of the emerged plant) $x$ 100. Root rot severity was scored 150 days after planting based on with the following ratings: 1no internal or external browning. 2- No internal browning, with superficial lesions of $\leq 25 \%$ on tap root. 3- Slight internal browning with $<25$ - $\leq$ $50 \%$ surface covered with cankers. 4- Moderate internal browning with $<50-\leq 75 \%$ cankers. 5Severe internal and external browning, i.e. rot covered $<75 \%$ of the root surface.

$$
\text { Disease severity }(\%)=\frac{\operatorname{Sum}(\mathrm{n} \times \mathrm{r} 0)+(\mathrm{n} \times \mathrm{r} 1)+\ldots .+(\mathrm{n} \times \mathrm{r} 4)}{4 \mathrm{~N}}
$$

Where: $n=$ No. of plants in each numerical rate (r0....r4). $\mathrm{N}=$ Total No. of plants multiplied by the maximum numerical rate (4).

\section{Assessment of the yield components}

At harvest, 150 days after planting, the yield was determined as weight of sugar beetroots (g), samples of the roots (4 replicate) of each cultivar were immediately transferred to the laboratory for total soluble solids and sucrose content assessments.

\section{Assessment of sucrose and total soluble solids} (TSS)

Sucrose \% and total soluble solids (TSS \%) was determined at harvest. The (TSS $\%)$ was determined in fresh roots using hand Refractometer ${ }^{14}$. While, sucrose percentage was estimated by adding $26 \mathrm{~g}$ from the minced root to $177 \mathrm{ml}$ of lead acetate $(50 \mathrm{~g} /$ /iter of distilled water), shacked for 5 minutes and filtered. The filtered solution was measured by Saccharometer as mentioned by Le-Docte ${ }^{15}$.

\section{Data analysis}

The tests were conducted with three replicates. Data were subjected to analysis of variance (ANOVA) and least significance difference (LSD) used to compare the means for all the variables within the experiment at $(P=0.05)^{16}$

\section{RESULTS}

$\beta$-glucanase enzyme synthesis increased rapidly during the first 20 hours of cultivation, though the highest levels were reached after 60 hrs. The changes in $\beta$-glucanase enzyme content during the growth of the selected bioagent reflect the changes in the growth rate during the different phases of the growth. The level is minimum when cells are in the lag phase, do not divide and their growth rate is low. As the cells start to divide, their number and the $\beta$ - glucanase enzyme content increase continuously as the growth rate reached its maximum value. This corresponds to the exponential phase of the culture, after which the culture enters the declaration phase. During this phase cell population continues to death, while the growth rate decreases continuously. During these two phases, the carbon sources become exhausted, and cells convert their products reserve to a form utilizable for their metabolism and division. Hence, paramylon level in the culture simultaneously decreases. The highest $\beta$ - glucanase enzyme concentration was reached $2000 \mathrm{U} / \mathrm{ml}$ (Fig. 1) reached in reduced time and energy only takes $60 \mathrm{hr}$ in contrast to the previous results ( in shake flask) giving $1354 \mathrm{U} / \mathrm{ml}$ that takes 6 days operation.

\section{Assessment of disease parameters}

Data presented in Table 1 indicated that, the treatment with $\beta$-glucanase enzyme enhanced seedling emergence, (after 15 days from planting), 


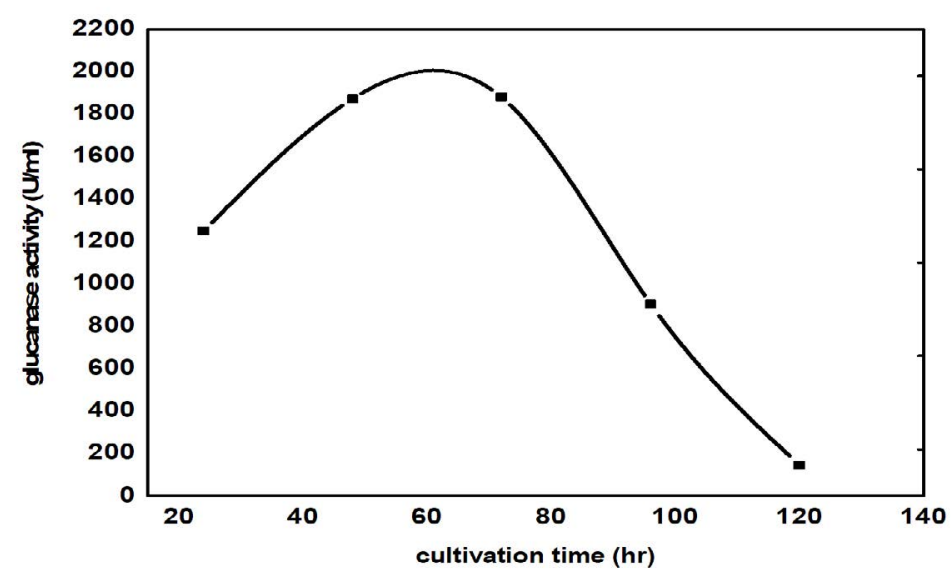

Fig. 1. Maximum $\beta$-glucanase enzyme production by bioreactor (it show max. production after $60 \mathrm{~h}$ )

Table 1. Effect of different treatments on sugar beet root rots disease during growing seasons

Treatments

Damping-off \%

\begin{tabular}{cccc}
$\begin{array}{c}15 \text { days } \\
(2016)\end{array}$ & $\begin{array}{c}15 \text { days } \\
(2017)\end{array}$ & $\begin{array}{c}45 \text { days } \\
(2016)\end{array}$ & $\begin{array}{c}45 \text { days } \\
(2017)\end{array}$ \\
\hline $0 \pm 0.0 \mathrm{e}$ & $5 \pm 0.0 \mathrm{~cd}$ & $15 \pm 0.5 \mathrm{c}$ & $17.5 \pm 0.5 \mathrm{~d}$ \\
& & & \\
$5 \pm 0.5 \mathrm{~d}$ & $7.5 \pm 0.5 \mathrm{bcd}$ & $27.5 \pm 0.5 \mathrm{~b}$ & $25 \pm 0.5 \mathrm{c}$ \\
$10 \pm 1.0 \mathrm{c}$ & $7.5 \pm 0.5 \mathrm{bcd}$ & $20 \pm 0.5 \mathrm{c}$ & $25 \pm 0.5 \mathrm{c}$ \\
$10 \pm 1.0 \mathrm{c}$ & $10 \pm 1.0 \mathrm{abc}$ & $30 \pm 0.5 \mathrm{~b}$ & $30 \pm 1.0 \mathrm{c}$ \\
$0 \pm 0.0 \mathrm{e}$ & $2.5 \pm 0.5 \mathrm{~d}$ & $5 \pm 0.5 \mathrm{~d}$ & $10 \pm 0.5 \mathrm{e}$ \\
$15 \pm 1.0 \mathrm{~b}$ & $12.5 \pm 0.5 \mathrm{ab}$ & $40 \pm 1.0 \mathrm{a}$ & $37.5 \pm 0.5 \mathrm{~b}$ \\
$20 \pm 1.0 \mathrm{a}$ & $15 \pm 0.5 \mathrm{a}$ & $42.5 \pm 1.0 \mathrm{a}$ & $45 \pm 0.5 \mathrm{a}$ \\
16.25 & 36.0 & &
\end{tabular}

15 days

15 days

$5 \pm 0.0 \mathrm{~cd}$

$15 \pm 0.5 \mathrm{c}$

$25 \pm 0.5 \mathrm{c}$

kj831197

Glucanase enzyme

T. harzianum kj831197

S. aromaticum

Vetavax fungicide

Control+talc

Control without talc

LSD cells of Trichoderma have the best results after fungicide comparing with the other treatments for disease control. Data in the Table 2 shown that after 150 days of planting, root rot infection whereas glucanase enzyme combined with

Table 2. Effect of different treatments on disease severity of roots after 150 days of growing time

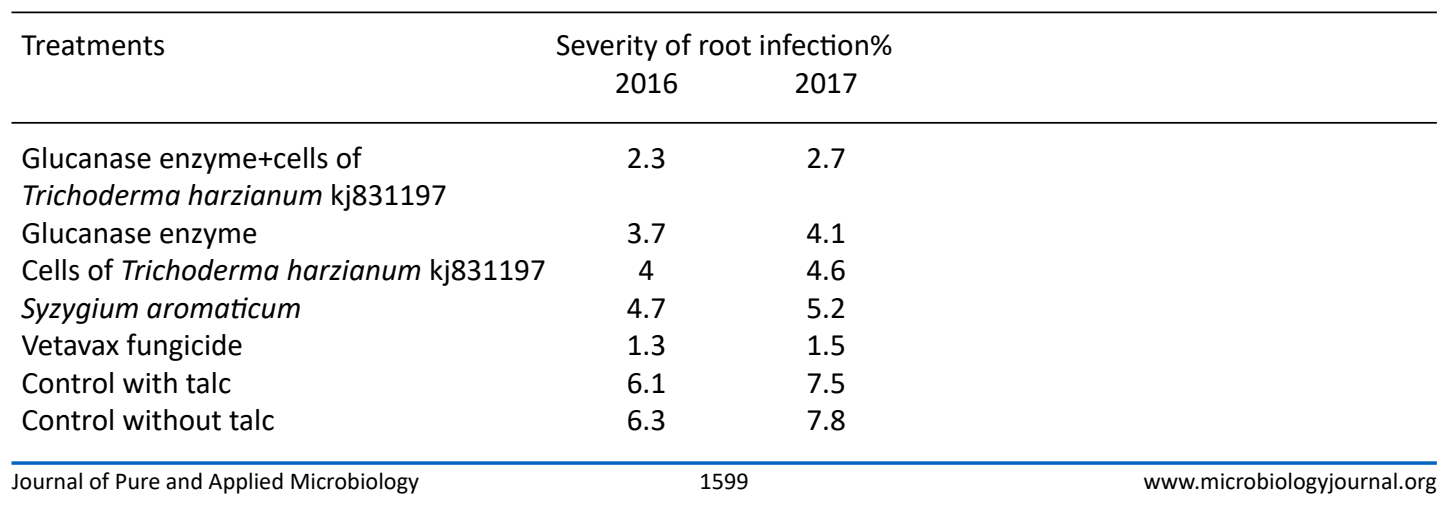




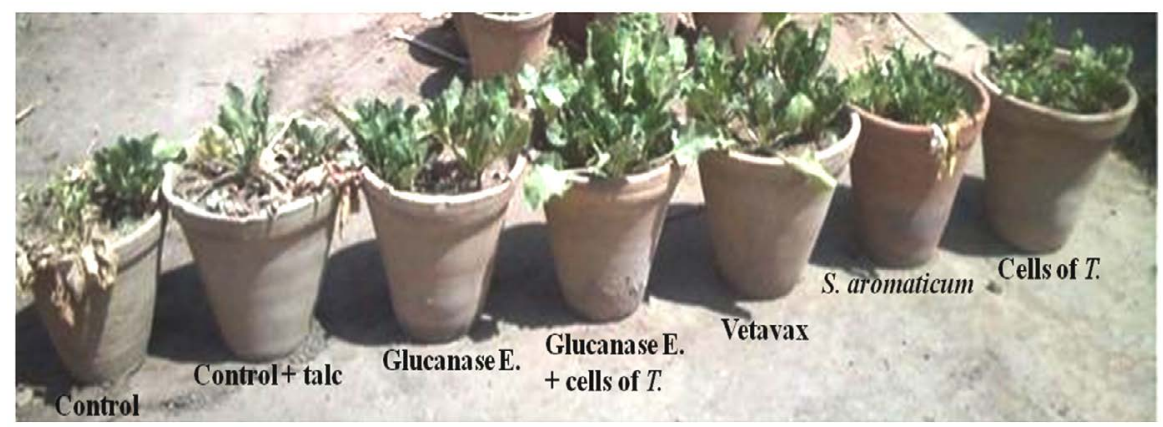

Fig. 2. Effect of different treatments on root rots disease severity of sugar beet

with S. rolfsii was significantly reduced due to any of treatments (Fig. 2). Data in Table 3 and (Fig. 3) Showed that the addition of glucanase enzyme only and in combination with cells of Trichoderma harzianum kj831197 increased the weight of sugar beetroots, while Syzygium aromaticum treatment ranked after them in weight of roots of sugar beet comparing to untreated control.

\section{Assessment of sucrose and total soluble solids (TSS)}

Data in Table 4 showed that the effect of the metabolites of Trichoderma (glucanase enzyme) and in case of its combination with cells of Trichoderma harzianum kj831197 compared to other treatments was increased TSS and sucrose content of sugarbeet. Significant differences were

Table 3. Effect of different treatments on weight of sugar beet roots under greenhouse conditions during growing seasons

\begin{tabular}{lcc}
\hline Treatments & \multicolumn{2}{c}{ Weight of sugar beet roots $(\mathrm{g})$} \\
& 2016 & 2017 \\
\hline Glucanase enzyme + & $291.53 \pm 0.03 \mathrm{a}$ & $295.59 \pm 0.02 \mathrm{a}$ \\
T. harzianum kj831197 & & \\
Glucanase enzyme & $192.84 \pm 0.06 \mathrm{~b}$ & $194.62 \pm 0.02 \mathrm{~b}$ \\
$T$. harzianum kj831197 & $182.38 \pm 0.02 \mathrm{c}$ & $192.07 \pm 0.02 \mathrm{~b}$ \\
S. aromaticum & $174.18 \pm 0.02 \mathrm{~d}$ & $100.9 \pm 0.02 \mathrm{c}$ \\
Vetavax fungicide & $92.63 \pm 0.02 \mathrm{e}$ & $90.18 \pm 0.02 \mathrm{~d}$ \\
Control+talc & $81.81 \pm 0.01 \mathrm{f}$ & $70.5 \pm 0.01 \mathrm{e}$ \\
Control without talc & $68.98 \pm 0.02 \mathrm{~g}$ & $69.18 \pm 0.01 \mathrm{e}$ \\
LSD & \multicolumn{2}{c}{224.48} \\
\hline
\end{tabular}

*Means value \pm SD, and LSD: least significant difference at $P \leq 0.05$

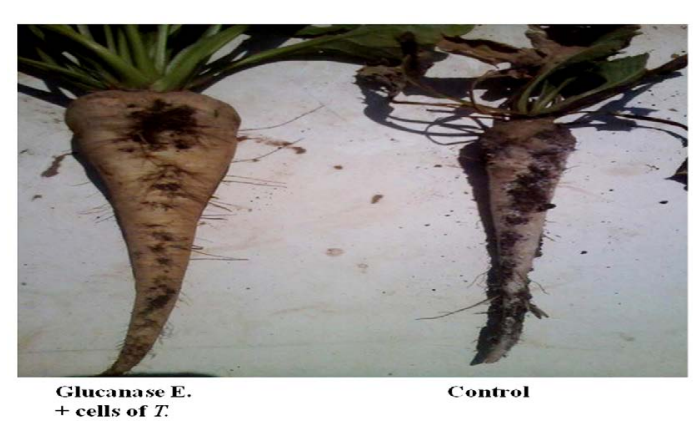

Fig. 3. Effect of application of $\beta$-glucanase enzyme and Trichoderma harzianum kj831197 cells on weight of sugar beet roots infected with $S$. rolfsii. found between values of TSS and sucrose content of sugarbeet as affected by combined treatments of glucanase enzyme and cells of Trichoderma harzianum kj831197. The highest reduction was detected in control with and without talc and also with Syzygium aromaticum and Vetavax fungicide treatments.

\section{DISCUSSION}

Sugar beet (Beta vulgaris L.) is considered as the second important source for sugar production following sugar cane in Egypt. Rootrot disease, caused by some common fungi, 
Table 4. Effect of different treatments on TSS, and sucrose content of sugar beet during growing seasons

\begin{tabular}{|c|c|c|c|c|}
\hline \multirow[t]{2}{*}{ Treatments } & \multicolumn{2}{|c|}{ TSS\% } & \multicolumn{2}{|c|}{ Sucrose \% } \\
\hline & 2016 & 2017 & 2016 & 2017 \\
\hline $\begin{array}{l}\text { Glucanase enzyme }+ \\
\text { T. harzianum kj831197 }\end{array}$ & $22.15 \pm 0.02 a$ & $20.42 \pm 0.02 a$ & $16.62 \pm 0.02 a$ & $18.1 \pm 0.02 \mathrm{a}$ \\
\hline Glucanase enzyme & $19.72 \pm 0.02 b$ & $18.51 \pm 0.02 b$ & $13.25 \pm 0.02 b$ & $14.15 \pm 0.02 b$ \\
\hline T. harzianum kj831197 & $16.9 \pm 0.02 c$ & $15.34 \pm 0.02 c$ & $12.45 \pm 0.3 c$ & $13.15 \pm 0.03 c$ \\
\hline S. aromaticum & $12.07 \pm 0.02 d$ & $10.09 \pm 0.03 d$ & $7.0 \pm 0.02 d$ & $10.87 \pm 0.02 d$ \\
\hline Vetavax fungicide & $10.12 \pm 0.01 \mathrm{e}$ & $8.175 \pm 0.02 \mathrm{e}$ & $5.75 \pm 0.04 \mathrm{e}$ & $8.870 .02 \mathrm{e}$ \\
\hline Control+talc & $9.7 \pm 0.02 \mathrm{e}$ & $7.082 \pm 0.01 f$ & $4.27 \pm 0.03 f$ & $7.17 \pm 0.025 f$ \\
\hline Control without talc & $9.2 \pm 0.03 e$ & $6.47 \pm 0.02 \mathrm{~g}$ & $4.05 \pm 0.02 f$ & $6.5 \pm 0.027 f$ \\
\hline LSD & \multicolumn{2}{|c|}{13.45} & \multicolumn{2}{|c|}{12.05} \\
\hline
\end{tabular}

${ }^{*}$ Means value \pm SD, and LSD: least significant difference at $P \leq 0.05$

Fusarium solani, Rhizoctonia solani and Sclerotium rolfsii were important diseases of sugarbeet causing severe crop losses. Sugarbeet was highly susceptible to root-rot disease caused by $S$. rolfsii and $R$. solani ${ }^{17}$. .

Biocontrol components may provide the correct values for infection tolerance as an alternative for certain chemical fungicides. Only a few microorganisms were fully marketable to protect foliar crop pathogens ${ }^{18}$. Trichoderma harzianum (Trichodex20SP), which can be regarded as a model of natural biocontrol agent to demonstrate its impact in agricultural conditions ${ }^{19}$. The formulation makes up originally of a microorganism and an additive serve as a carrier. Powder or granular inert components can be combined matrices such as rock wool and peat-based mixtures, clays, kaolin clay, montmorillonites, saponites, mica, perlites, vermiculite, talc. Support for preserving and the safety of the microbes against the impact during storage and ship should be steady and pure to set and distribute. All formulations are still requested to be efficient ${ }^{20}$.

Adequate volume is required with both solid and liquid formulations for effective and viable Trichoderma inocula. The fluid model is advanced with the aim of maximizing biomass output and effectiveness by regulating nutrient components, $\mathrm{pH}$ and temperatures as well as additional development factors that cause contamination to decrease ${ }^{21}$. That is what we do in our study; by comparing the obtained results in bioreactor for large scale production of bioagent and its components with those previously obtained in shake flask or solid-state fermentation at the same condition, we gained maximum enzyme activity at shake flask reached $1354 \mathrm{U} / \mathrm{ml}$ after 6 days (under publications), while at bench top fermentor it reached more than this level $(2000 \mathrm{U} / \mathrm{ml})$ with little time (60hr only). This high value of enzyme activity at bench top fermentor may be due to the use of considerable level of gas flow which equal to $1 \mathrm{vvm}$ and controlled growth conditions of agitation, $\mathrm{pH}$ and aeration. Accordingly, results obtained in a shake flask should be taken only as preliminary indicators of the conditions necessary for successful scaling up bioagent production and must be verified in studies carried out in a fermentor. The dissolved oxygen (DO) rapidly decreases during the exponential growth phase because of the respiration of the cells. During the stationary phase (DO) levels increases probably because of a decrease in the respiration rate of Trichoderma cells. This increase of dissolved oxygen is due to the lack of substrate and is used as a signal to feed the fermentor ${ }^{22-23}$.

Results of this research demonstrate that Trichoderma harizianum kj8311197 produce a high quantity of $\beta$-glucanase enzyme. The $\beta$-glucanase enzyme developed by the Trichoderma has been greatly reduced the radial size of the $S$. rolfsii that was in agreement with Mala et al. ${ }^{24}$.

One of the principal processes for antagonistic action against phytopathogenic fungi was the immediate mycoparasitic action 
of Trichoderma species ${ }^{25}$. Trichoderma fungal species produce distinctive hydrolytic enzymes used as biocontrol agents that show a key role in cell wall deterioration. Hydrolytic enzymes include chitinase, glucanase, protease and cellulase ${ }^{26}$. Castillo et al. ${ }^{27}$ found that $T$. longibrachiatum and T. asperellum were the most efficient species with the highest antagonist effects against Sclerotinia sclerotiorum and Sclerotium cepivorum among Mexicans Trichoderma strains.

Chakraborty et al. ${ }^{28}$ recorded that combined therapy of Bradyrhizobium japonicum and Trichoderma harzianum markedly lowered Soya bean plant rot infection. The proposed mechanisms of Trichoderma as antagonistic bioagent were identified: (1) powerful mineral fight; (2) antibiotic development through helpful microorganisms; (3) successful predation against pathogens by secretion of hydrolytic enzymes. These fungi can, therefore, stimulate root development, regulate deleterious pathogenic microflora, the decay of harmful microflora producing toxic metabolites and regulate the root pathogens immediately. Today, in several agricultural provinces more than 50 different agricultural products depending on Trichoderma are applicable and result in higher plant revenues ${ }^{29}$. Recently, biological control agents (BCAs) based on Ttrichoderma has grown to approximately $60 \%$ of all fungal BCAs. T. Harzianum has lately been used as an effective element in various commercially available biopesticides ${ }^{30-32}$. Marketing of biocontrol agents are a multi-step method including microorganism isolation, selection of the best antagonistic isolate in laboratory circumstances and field environments, mass processing, formulations, production and compatibility 4 .

Addition of glucanase enzyme of Trichoderma harzianum kj831197 to cells of Trichoderma harzianum kj831197 increased the yield components i.e. the average of roots weight while both of Vetavax fungicide and Syzygium aromaticum reduced the yield components. Our early work demonstrated that Trichoderma sp. did indeed have the ability to control plant diseases. Obviously, the level of efficacy and the reliability of simple approaches to biocontrol gave results that were substantially equal to that of commercial fungicides. Glucanase enzyme of Trichoderma harzianum kj831197, enhance plant growth and productivity. Aly and Hussein ${ }^{33}$ discovered that sugar beet crops already have $T$. harzianum treatment giving rise high proportion of the new and dry weight of the leaves and sugar beet's roots when contrasted to control. Our results recorded significant differences between values of total soluble solids (TSS), sucrose contents of sugar beet affected by combined $\beta$-glucanase enzyme and cells of Trichoderma harzianum kj831197. All of the treatments showed an increase in \% of TSS and sucrose contents except control treatment, which showed a significant reduction. The addition of Vetavax 200 fungicide caused a reduction in the total soluble solid \% (TSS) and sucrose contents Also, the use of Syzygium aromaticum individually showed low values of percentage of TSS and sucrose contents. The lowest percentages of TSS and sucrose contents were obtained from treatments of S. rolfsii only. These results in agreement with Aly and Hussein ${ }^{33}$, they reported that sugar beet crops handled with Trichoderma were revealed to be sucrose levels (\%) greatly above the other medications or treatments. In addition, the sugar beet crops inoculated with Trichoderma was significantly improved in purity (\%). Total soluble solids \% was significantly enhanced when handling beet plants of Rhizoctonia and Trichoderma in contrast with the control of the 1st and 2 nd growing seasons. Dovil et al. ${ }^{34}$ observed the small impact of fungicides on sugar beet yield and sucrose quantity. The Trichoderma sp. can grow in a wide range of habitats and this is achieved by evolved diversified metabolic enzymes and secondary metabolites. Production of commercially important enzymes such as amylases, cellulases, 1-3 $\beta$-glucanases, and chitinases were extensively studied and this technology is continuously being updated ${ }^{35-37}$.This unique methods for using hydrolytic enzymes as a biocontrol agent have been raised the agricultural production in all horticultural sectors and immediately find environmentally friendly solutions to overcome problems caused by the standard chemical methods of plant protection.

Current attempts are now underway of increasing the output of hydrolytic enzymes (Glucanase) by fermenting agricultural waste materials and by optimizing growth conditions. 


\section{ACKNOWLEDGEMENTS}

We wish to thank Prof. Dr.-Ing. Usama Beshay, City for Scientific Research \& Technology Applications, Genetic Engineering \& Biotechnology Research Institute (GEBRI), Bioprocess Development Dept. for further help in using equipments throughout the studies, chemical and tools of his projects.

\section{CONFLICT OF INTEREST}

The authors declare that there are no conflict of interest.

\section{AUTHORS' CONTRIBUTION}

This work was carried out in collaboration between all authors. SAE designed the study, wrote the protocol, wrote the first draft of the manuscript, supported the fermentation experiment and molecular identification of trichoderma strain in GenBank, and managed the work of all experiments of the study with all authors. MMG and SME shared all the experiments, analyzed the data, wrote the manuscript and performed the statistical analysis. MNA did isolate and purify all strains, Performed enzyme assay and other analysis. AMB provided assistance in lab with continuous management, share the work of experiments, managed the literature searches, wrote paper with other authors. All authors read, revised and approved the final manuscript.

\section{FUNDING}

This work was supported by the Ministry of Scientific Research, Egypt under the coordination project between Egypt and Tunisia.

\section{DATA AVAILABILITY}

All data generated or analyzed during this study are included in this published article (some previous data study is under consideration for publication and are available from corresponding author upon reasonable request). Sequence of Trichoderma harzianum of this study have been deposited in GenBank with accession code kj831197.

\section{ETHICAL STATEMENT}

This article does not contain any studies with human participants or animals performed by any of the authors.

\section{REFERENCES}

1. Hassan, M. , Abdelouahid El-khattouti, Youssef H., Mosaad M. Signaling Pathways as Therapeutic Target in Tumor Treatment. Cell Signaling, 2014; 2 (1): 1-20. https://doi.org/10.14259/cs.v2i1.97

2. Fatouh, HMM. Pathological studies on sugar beet root rot. M.sc. 2012. Thesis Botany. Dept. Fac. Agric. Benha Univ., Egypt.

3. Bartholomaus, A., Mittler S., Marlander B.,Varrelmann M. Control of Rhizoctonia solani in sugarbeet and effect of fungicide application and plant cultivar on inoculum potential in the soil. Plant disease, 2017; 101: 941-947. https://doi.org/10.1094/PDIS-09-16-1221-RE

4. Muhammad U.G, Mubashar R., Waqas R., Misbah IQ. Trichoderma as potential biocontrol agent, its exploitation in agriculture: a review of plant Protection, 2018; 02 (03): 109.

5. Helal, M.I. Control of damping-off disease in some plants using environmentally safe biocides Pak. J. Bot., 49(1): 361-370.

6. Cook, R.J, Baker, K.F. 1989. The Nature and Practice of Biologial Control of Plant Pathogens. APS Press, St. Paul. 539. P

7. Cook, 1985. Biological control of plant pathogens: theory to application. Phytopathology, 75; 25-29. https://doi.org/10.1094/Phyto-75-25

8. Whipps. Status of biological disease control in horticulture. Biocontrol Science and Technology, 1992; 2(1):3-24. https://doi.org/10.1080/ 09583159209355213

9. Elad, Y., Chet, I., Boyle, P.,Henis, Y. Parasttism of Trichoderma spp. on Rhizoctonia solanii and Sclerotium rolfsii. Scanning electron microscopy and fluorescent microscopy. Phytopathology., 1983;73:85-88. https:// doi.org/10.1094/Phyto-73-85

10. Miller, G.L. Use of dinitrosalicylic acid reagent for the determination of reducing sugar. Anal. Chem., 1959; 31: 426-428. https://doi.org/10.1021/ac60147a030

11. Kumala, S., Anggraeni P. Handayani. Isolation of endophytic fungi from dipterocarpus grandiflorus blanco and evaluation of xylanase enzyme activity from fermentation broth, IJPSR, 2011; 2(1): 63-68.

12. Abd-El Moity, G.C, Shatla, MN. Induction of new isolates of Trichoderma harzianum tolerant to fungicides and their experimental use for control of white rot of onion. Phytopatology, 1982; 72: 396-400. https://doi.org/10.1094/Phyto-72-396

13. El-Shafey H.A, El-Shorbagy F.A, Khalil II, El-Assiuty E.M. Additional sources of resistance to the late-wilt disease of maize caused by Cephalosporium maydis. Agricultural Research Review, 1988; 66:221-230.

14. Me Ginnis, R.A. Beet sugar technology. 3rd Ed. Beet Sugar Development Foundation Fort Collins. 1982; 855.

15. Le-Docte, A. Commercial determination of sugar in beetroots using the Sacks. Le-Docte Process. Int. Sugar. J., 1927; 29: 488-492.

16. Gomez, K.A, Gomez, K.H. 1984. Statistical Procedures for agricultural research ( $2^{\text {nd }}$ Edition). New York: John Willy and Sans Press.

17. Nishimura, N., Shiomi, T., Ikegaya, F. Susceptibility of corn to Rhizoctonia root -rot and differences between isolates in pathogenicity. Proceeding of the Association 
for P1.Protection of Kyushu., 1991; 37: 6-8. https://doi. org/10.4241/kyubyochu.37.6

18. Fravel, D.R.1999. Web site for the USDA/ARS biocontrol of plant diseases laboratory (http://www.barc.usda. gov/psi/bpdl/bioprod.htm).

19. Elad, Y. Biological control of grape grey mould by Trichoderma harzianum. Crop Prot, 1994; 13:35-38. https://doi.org/10.1016/0261-2194(94)90133-3

20. Xavier, I..; Holloway, G., Leggett, M. 2004. Development of Rhizobial Inoculant Formulations, In: Plant Management Network, 14.01.2003, Available from http://www.plant management network.org/pub/cm/ review/2004/develop/, Crop Manage. ISSN 1543-7833.

21. Whipps, JM. 1997. Ecological considerations involved in commercial development of biological control agents for soil-borne diseases. In: van Elsas, J.D, Trevors J.T, Wellington EMH, eds. Modern soil microbiology. New York: Marcel Dekker, 525546.

22. Dewitt, D., Jackson, J.V, Paulus, TJ. 1989. Actinomycetes. In Fermentation Process Development of Industrial Organisms, (Justin, O. Neway). Marcel Dekker, inc., 27.

23. Suh, I.S, Lee, CG. photobioreactor engineering: Design and performance Biotechnology and Bioprocess Engineering., 2003; 6:313-321. https:// doi.org/10.1007/BF02949274

24. Mala, R., Sarojini, M., Saravanababu, S., Umadevi, G. screening for antimicrobial activity of crude extracts of Spirulina platensis. J Cell \& Tissue Res., 2009; 9(3): 1951-1955.

25. Chet, I., Hadar, Y., Elad, J., Katan, HY. 1979. Biological control of soil borne plant pathogens by Trichoderma harzianum. Pages 585-591 in: B Schippers and W. Gams, eds. Soil Borne Plant Pathogens. Academic Press. London.

26. Mabood, F., Xiaomin Z., Donald L. Smith Microbial signaling and plant growth promotion. Can. J. Plant Sci., 2014; 94: 1051-1063. https://doi.org/10.4141/ cjps2013-148

27. Castillo, F.D, Padilla A.M, Morales G.G, Siller M.C, Herrera R.R, Gonzales C.N, Reyes F.C. In vitro antagonist action of Trichoderma strains against Sclerotinia sclerotiorum and Sclerotium cepivorum. American Journal of Agricultural and Biological Science, 2011; 6: 410-417. https://doi.org/10.3844/ ajabssp.2011.410.417
28. Chakraborty, U., Sarkar B., Chakraborty BN. Combined application of Bradyrhizobium japonicum and Trichoderma harzianum on root rot disease of soyabean. J. Mycol. PI. Pathol., 2003; 33: 21-25.

29. Woo, S.L, Ruocco M., Vinale F., Nigro M., Marra R., et al. Trichoderma based products and their widespread use in agriculture. Open Mycol J, 2014; 8:71-126. https:// doi.org/10.2174/1874437001408010071

30. Lorito M., Woo S.L. Trichoderma: A multi-purpose tool for integrated pest management in Principles of plant-microbe interactions. Springer, 2015; 345-353. https://doi.org/10.1007/978-3-319-08575-3_36

31. Vinale, F., Sivasithamparam K., Ghisalberti E.L, Marra R, Woo S.L, et al. Trichoderma-plant-pathogen interactions. Soil Biol Biochem, 2008; 40: 1-10. https:// doi.org/10.1016/j.soilbio.2007.07.002

32. Oros, G., Naar Z., Cserhati T. Growth response of Trichoderma species to organic solvents. Mol. Inf., 2011; 30:276-285. https://doi.org/10.1002/ minf.201000097

33. Aly, M.H, Hussein, M.Y. Vesicular - Arbuscular Mycorrhiza and Trichoderma viridi as deterrents against soil-borne root rot disease of sugar beet. Sugar tech, 2009; 11: 387 - 391. https://doi.org/10.1007/ s12355-009-0066-9

34. DovilJ, A., Zita B., Kךstutis R, Antanas M. Efficacy of fungicides in sugar beet crops. ZemdirbysteAgriculture, 2016; 103, (2): 167 174. https://doi. org/10.13080/z-a.2016.103.022

35. Harman, G.E, Lorito, M., Lynch, JM. Uses of Trichoderma spp. to alleviate or remediate soil and water pollution. Advances in Applied Microbiology, 2004; 56: 313-330. https://doi.org/10.1016/S0065-2164(04)56010-0

36. Ahamed, A., Vermette, P. Effect of culture medium composition on Trichoderma reesei's morphology and cellulase production. Bioresource Technology, 2009; 100: 5979-5987. https://doi.org/10.1016/j. biortech.2009.02.070

37. Sandhya, C., Leela K. A, Madhavan Nampoothiri K, Ashok P. Extracellular chitinase production by Trichoderma harzianum in submerged fermentation. Journal of Basic Microbiology , 2004; 44(1):49-58. https://doi.org/10.1002/jobm.200310284 